\title{
Madness, Dissidence and Transduction
}

\section{Craig Stewart Walker ${ }^{1}$}

Recibido: 2016-09-16

Enviado a pares: 2016-09-17
Aprobado por pares: 2017-02-17

Aceptado: 2017-03-16

DOI: 10.5294/pacla.2017.20.3.5

Para citar este artículo / to reference this article / para citar este artigo

Walker, C.S. (2017). Madness, dissidence and transduction. Palabra Clave, 20(3), 686-701. DOI: 10.5294/pacla.2017.20.3.5

\section{Abstract}

Russian dissident artist Pyotr (or Petr) Pavlensky received international attention after a video was broadcast in 2013 that depicted him sitting in Red Square in Moscow with his scrotum nailed to the cobblestones. The incident was later revealed to be part of a series of works of performance art enacted by Pavlensky, which included sewing his own mouth shut, appearing naked within a coil of barbed wire in front of the legislature, building a mock barrier of flaming tires in downtown St Petersburg in imitation of the political uprisings in Kiev, cutting off his own ear while sitting naked on the wall of the Serbsky Psychiatric Hospital, and setting fire to the wooden doors of the headquarters of the Russian Secret Service. Although the Russian authorities have attempted on several occasions to treat Pavlensky as if he were criminally insane, he continues to articulately defend his activities as works of dissident political art. This article explores the idea that Pavlensky is deliberately using transduction as a tool through which his work achieves meaning. Pavlensky consciously invokes two different fields of cultural interpretation. The first is the adherence of authorities to the Russian Criminal Code, which is used to exert despotic control over the Russian people. The second is the international discourse surrounding avant-garde art,

1 Queen's University. Canada. craig.walker@queensu.ca 
which champions freedom of expression, including dissident works. By ensuring that there is a transduction of his work from the first field to the second, Pavlensky creates a collision of opinion in which the legitimacy of Russian state policy is challenged and delegitimized.

\section{Keywords}

Pavlensky; transduction; dissident; performance; art (Source: Unesco Thesaurus). 


\section{Locura, disidencia y transducción}

\section{Resumen}

El artista disidente ruso Piotr (o Petr) Pavlensky recibió atención internacional luego de que en 2013 se transmitiera un video en el que aparecía sentado con los testículos clavados a los adoquines de la Plaza Roja de Moscú. Posteriormente, se reveló que el incidente hacía parte de una serie de acciones artísticas de Pavlensky, que incluyeron coserse la boca, aparecer desnudo dentro de un rollo de alambre de púas frente a la sede de la Asamblea Legislativa, construir una barrera de neumáticos en llamas en el centro de San Petersburgo, haciendo alusión a los levantamientos políticos en Kiev, cortarse su propia oreja mientras se sentaba desnudo en la pared del Hospital Psiquiátrico de Serbsky y prender fuego a las puertas de madera del cuartel general del Servicio Secreto ruso. Aunque las autoridades rusas han intentado en varias ocasiones tratar a Pavlensky como si estuviera criminalmente loco, él sigue defendiendo de manera articulada sus actividades como obras de arte político disidente. Este artículo explora la idea de que Pavlensky usa deliberadamente la transducción como una herramienta por medio de la cual su trabajo cobra sentido. Pavlensky invoca conscientemente dos campos diferentes de interpretación cultural. La primera es la adhesión de las autoridades al Código Penal ruso, que se utiliza para ejercer un control despótico sobre el pueblo ruso. El segundo es el discurso internacional que rodea el arte de vanguardia, que defiende la libertad de expresión, incluidas las obras disidentes. Al asegurar que hay una transducción de su trabajo desde el primer campo al segundo, Pavlensky crea una colisión de opinión en la que la legitimidad de la política estatal de Rusia es desafiada y deslegitimada.

\section{Palabras clave}

Pavlensky; transducción; disidencia; interpretación; arte (Fuente: Tesauro de la Unesco). 


\section{Loucura, dissidência e transdução}

\section{Resumo}

O Artista dissidente russo Piotr (ou Petr) Pavlensky recebeu atenção internacional depois da transmissão em 2013 de um vídeo onde aparecia sentado com os testículos pregados nos paralelepípedos da Praça Vermelha em Moscou. Depois foi revelado que o incidente era parte de uma série de obras de arte performática realizadas por Pavlensky, que incluíram costurar a própria boca, aparecer nu e enrolado em arame farpado em frente à Assembleia Legislativa, construir uma barreira de pneus em chamas no centro de São Petersburgo, imitando as revoltas políticas em Kiev, cortar a orelha sobre o muro do Hospital Psiquiátrico de Serbsky e incendiar as portas de madeira do quartel-general do serviço secreto russo. Embora as autoridades russas tenham tentado em várias ocasiões tratar Pavlensky como se fosse um louco-criminoso, ele continua defendendo articuladamente suas atividades como obras de arte política dissidente. Este artigo explora a ideia de que Pavlensky usa deliberadamente a transdução como uma ferramenta através da qual seu trabalho alcança significado. Pavlensky invoca conscientemente dois campos diferentes de interpretação cultural. A primeira é a adesão das autoridades ao Código Criminal russo, que é usado para exercer controle despótico sobre o povo russo. $\mathrm{O}$ segundo é o discurso internacional em torno da arte de vanguarda, que defende a liberdade de expressão, incluindo as obras dissidentes. Ao assegurar que haja uma transdução de seu trabalho desde o primeiro campo para o segundo, Pavlensky cria uma colisão de opinião em que a legitimidade da política do Estado russo é desafiada e deslegitimada.

\section{Palavras-chave}

Pavlensky; transdução; dissidência; performance; arte (Fonte: Tesauro da Unesco). 
Is cultural transduction merely something that happens to a given work, or can it be intended and planned for by the creator of the cultural artifact? This is the question I explore in this essay. I am aware that I am not using the theory of cultural transduction in exactly the manner contemplated by those who invented the concept, Enrique Uribe-Jongbloed and Hernán Espinosa, but I hope that my use of the term, rather than eroding the authority of their theory, extends it.

The call for papers for the May 2016 "Conference on Cultural Transduction” at the Universidad del Norte in Barranquilla, Colombia offered the following definition: "Cultural Transduction may be understood as the process sustained by any product from a given cultural market that has transcended the original market and extended beyond the place where the original idea or product was designed" (Universidad del Norte, 2016). That phrase, "the process sustained by any product", implies a passive role. Transduction is what happens to the product, it is not something that the product does. And I have a great appreciation for how important this concept is in our world of global cultural interchange. In many cases, of course, the effect of transduction is a violent redefinition of the work in question.

But could a transduction also be planned and deliberate? I am thinking of a process that could be compared to the metamorphosis of a caterpillar into a butterfly or a tadpole into a frog. Metamorphoses such as these are programmed into the creature's DNA. It is genetically coded within the tadpole that it should undergo a metamorphosis associated with a change of environments. Is it also possible to conceive of a work of art in such a way that its transduction, as it leaves one sphere of interpretation and enters another, is an intentional part of its ultimate meaning? Can we consider cultural transduction, in addition to its other meanings, to be also a potentially important tool that lies within an artist's reach?

I have one such artist in mind: the Russian performance artist and activist Pyotr Pavlensky.

On a damp and chilly Sunday in November 2013, Pyotr Pavlensky walked into Moscow's Red Square, stripped himself naked, sat down, and 
nailed his scrotum to the cobblestones. Once his accomplice had departed with clothes and hammer, Pavlensky remained alone, silent, and motionless. It was one o'clock, lunchtime, so there were plenty of tourists and other passersby in Red Square to stare down in horror at this spectacle. Pavlensky, in turn, stared down expressionlessly at what he had done, waiting patiently for the authorities to respond ("Artist Peter," 2013). Before long, the police arrived and demanded that those who were filming the incident with their cellphones desist. An ambulance was called, and by $2: 30$, they had managed to remove the long spike from the cobblestones and take Pavlensky to First City Hospital for treatment. Although Pavlensky permitted an examination, he refused to be admitted at the hospital, insisting that the wound was nothing serious (Walker, 2013). "The body is a strong material and pain is often mere fear, mere phobia," he would say later (Galperina, 2013). So, instead, he was taken to police headquarters and charged with "hooliganism," a crime in Russia that is punishable by up to five years imprisonment. Given that, at that very time, two members of the rock band Pussy Riot were still serving sentences for hooliganism in connection with their February 2012 performance at Moscow's Cathedral of Christ the Saviour, there was reason for Pavlensky to be concerned (Stanglin, 2014).

The incident in Red Square was not the first time that Pavlensky had caused harm to himself in public. In July 2012, Pavlensky had sewn his own mouth shut, and stood with a sign protesting the incarceration of members of Pussy Riot until the police hauled him off to a hospital to have the sutures removed from his lips (Remax1162, 2012). In May 2013, he had appeared with his naked body wrapped in a cocoon of barbed wire on the steps of the St. Petersburg legislature (Skameikin, 2013). However, the Red Square incident not only received much wider international coverage, it represented a new, more sophisticated approach to his media manipulation. It was with that case that his foray into transduction began, as I shall explain in due course.

As it happened, the charges against Pavlensky for the Red Square incident were eventually dropped in April 2014 (Stanglin, 2014). But in the meantime, he had been arrested again with a group of accomplices, for setting fire to a mound of tires in the middle of the night on the Little 
Konushennaya Bridge in St. Petersburg in February 2014. The tires formed a barricade, but there was nothing for the barricade to protect or to ward off. There is a film of the barricade of tires being put in place and set on fire that makes clear that the streets are deserted. Once the barricade was aflame, Pavlensky and his accomplices banged loudly on metal sheets, shouted Ukrainian slogans and waved the Ukrainian flag, which gave the impression to the awakened onlookers that one of the violent protests in Kiev had somehow been transplanted to St Petersburg. When the police arrived, the group was arrested at first for hooliganism, the same charge as Pavlensky had faced in Moscow, but two days later the charge was reduced to vandalism.

In October 2014, Pavlensky mounted the wall of the Serbsky Psychiatric Hospital, which became infamous during the Soviet era for labeling political dissidents as mentally ill and confining them to psychiatric wards until they recanted their political beliefs. Under Vladmimir Putin, the practice had been resumed, according to Amnesty International (Luhn, 2014a). Pavlensky sat there naked on the wall that separated the allegedly sane from the allegedly insane and cut off one earlobe with a large butcher knife. Then, again, he waited for the police to come and arrest him (Hlyupin, 2014).

In November 2015, Pavlensky took an even greater risk, setting fire to the wooden doors of Lubyanka, the headquarters of the Russian Secret Service, the FSB, formerly the KGB ("Russian artist," 2015). It was in this building that countless political dissidents were tortured during the Soviet era. Pavlensky had himself photographed and videoed standing in front of the burning doors holding the empty can of gasoline he had used. Again, he waited there patiently until he was arrested, as a news video showed. This time, he was sent to psychiatric hospital for assessment. In a further irony, the hospital was the Serbsky. However, after a month of psychiatric assessment, Pavlensky was declared sane and taken to court ("Pavlensky Refused," 2016). There, he demanded that the charges against him be raised from vandalism or arson to a charge of terrorism. Pavlensky based this request on the precedent that this had been the charge upon which Ukrainian film director Oleg Sensov had been sentenced to 20 years in prison after being accused of setting fire to the offices of the Russian Community of Crimea organization-an accusation that Sensov denied (Walker, 2015). 
By contrast, Pavlensky has never attempted to elude the police and indeed has taken special pains to ensure that he is charged to the full extent of the law. In the case of the charges of vandalism, the prosecution had proceeded reluctantly with the case; but when, last month, in April 2016, they offered to drop the charges because of the time elapsed, Pavlensky refused and insisted that his case be heard ("Pavlensky Refused," 2016). Moreover, his activities over the past few years have all deliberately invited an initial judgement that they are symptomatic of insanity. That is certainly what the police who found him with his scrotum nailed to Red Square believed, and it was again the assumption made by those who found him recreating a Kiev protest in St Petersburg, or sitting naked and bleeding on the wall of an insane asylum or standing calmly in front of the door of the most feared and powerful office of the government having just set it alight. In each instance he has been assumed by the authorities to be what we used to call "criminally insane."

But the fact is that Petr Pavlensky is extremely well ordered and rational in his mind, and he is deeply moral in his stance towards the rest of the world. Part of this moral stance is evident in his care to ensure that he faces the authorities after each act.

"I think," he has said, "that would have discredited everything I'd done before, if at the first sign of danger I'd gone into hiding. So I decided to take a position of strength, because there is nothing to be afraid of. You can be afraid if you feel you are guilty of something and I don't. Anything the authorities do against me means discrediting themselves. The more they do with me, the worse they make it for themselves... The authorities are in a deadend situation and don't know what to do." (Walker, 2014).

His earlier works, such as Seam, for which he sewed his mouth shut or Carcass, for which he was cocooned within barbed wire, were immediately and clearly apprehensible as performances of political protest. But starting with the incident in Red Square, Pavlensky carefully arranged matters so that, on the one hand, it would be inevitable that he would be arrested and that in the first instance both onlookers and the authorities first 
to respond would assume that they had witnessed an act of crime and/or madness. On the other, he had arranged for an explanation in each case to appear internationally on the Internet, sometimes through the agency of his artistic partner and wife, Oksana Shalygina. Only when seen through the context provided by his comments on the Internet was each of the incidents revealed to be an artistic performance.

The incident in Red Square was called Fixation. Notwithstanding that many people declared that Pavlensky was mentally ill or a masochist, (Serebrennikov, 2013), that it was treated as hooliganism by the police, and that it was reported as a suicide attempt on the Russian state television station (Sedacca, 2015) -a declaration that shows a remarkably tenous grasp of anatomy-, Pavlensky insisted that the event was a work of art. He offered the following description on the website grani.ru: "A naked man sitting in Red Square, looking at his balls [Pavlensky actually used the Russian slang, 'eggs'] nailed to the Kremlin pavement. The action," he continued, "can be seen as a metaphor of the apathy and political indifference and fatalism of the modern Russian society." He had timed the action to coincide with Russia's Police Day and also the seventy-fifth anniversary of Kristallnacht. He contended that post-Soviet Russia had become a police state in which the Russian people sat transfixed, convinced they were impotent to overthrow tyranny despite their superior numbers ("Artist Peter," 2013). The global artistic world accepted the idea that Fixation was a work of art. In the Calvert Journal, art experts from all over the world discussed the action, and the greatest controversy was whether the event was an original work of art or excessively derivative of previous work, (Ekow, Omidi, Rann, \& Zinatulin, 2014), such as that of the late American performance artist Chris Burden, who made a name for himself in the 1970s with events such as one where he had himself shot in the arm and another in which he was crucified to the back of a Volkswagen (Moyer, 2015).

In the case of the burning barricade of tires on the Little Konushennaya Bridge, Pavlensky had called the incident Freedom. He pointed out that no damage was done to the bridge, so it was not an act of vandalism, that no one was in danger, and that it was only recognizable as a political act by means 
of comparison to the events in Kiev. As a work of art, it was in one respect a sympathetic tribute to the protests in the Ukraine, but it was also a comment on the less visible oppression at home in Russia.

The incident in which he cut off his earlobe while sitting on the wall of the Serbsky Psychiatric Hospital was called Segregation. Naturally, the work alluded to Van Gogh's act of desperation and commented on the use of psychiatric treatment to coerce political dissidents, but again, Pavlensky used the Internet to dilate interpretation, offering Segregation as a metaphor for life in Russia under Putin: "Arming himself with psychiatric diagnoses, the bureaucrat in a white lab coat cuts off from society those pieces that prevent him from establishing a monolithic dictatorship in which there is a single, mandatory norm for everyone" (Luhn, 2014b).

The incident in which he set fire to the door of the Russian Secret Service Headquarters was simply called The Burning Door of Lubyanka (Agence France-Presse, 2015). In a video that has since been deleted from Vimeo, Pavlensky explained that "the FSB used the methods of terrorism to exert their power over 146 million people. The threat of inevitable reprisals hangs over everyone within the range of security cameras, phone-tapping and passport control borders" (Agence France-Presse, 2015). Afterwards, Twitter erupted with artistic discussion of Pavlensky's action, with more than one commentator pointing out that the sight of the door of Lubyanka on fire suggested the burning gates of hell ("Russia Update," 2015). In short, within the international art world, Pavlensky is not only well understood, he has been embraced and lionized. In March of this year, a bust of Pavlensky by sculptor Gintautas Lukoshaytis was erected as a monument to citizenship in Vilnius, Lithuania ("In Vilnius," 2016).

So, to this point, my argument is clear enough. At the time Pavlensky has performed each of his actions, they have been received by onlookers and the authorities as acts of criminal insanity. But through his use of the Internet, they have been presented and received as artistic works that make political statements. "For me," Pavlensky has said, "political art means revealing the levers and mechanisms of power" (Lichtfilm, 2016). But can we go so far as to say that Pavlensky is making use of transduction in his work? 
What convinced me that Pavlensky was doing just this was his interrogation by Pavel Jasman, an agent from the powerful Russian Investigative Committee, which Putin had set up to ensure that prosecutions were expedited (Whitmore, 2007). The interrogation of Pavlensky by Jasman took place in three sessions over the period of March to June 2014 (Nechepurenko, 2015). The interrogation had been initiated in response to Freedom, the incident in which Pavlensky and his accomplices set up the barricade of burning tires in St Petersburg. It ended when Jasman decided to quit his job and announced publicly that he was going to support Pavlensky. This conversion seems like the stuff of comedy, but it happens to be well documented. Unknown to Jasman, Pavlensky recorded the entire interrogation and then later allowed the transcripts to be published.

In the transcripts, Pavlensky avoids directly addressing the details of the burning tires by invoking Article 51 of the Russian constitution, which protects the right to avoid self-incrimination (De Winne, 2014). Instead, he draws Jasman, who at 30 was one year younger than Pavlensky, into a discussion of art. At the beginning Jasman impatiently dismisses Pavlensky's framing of his actions as art: "What's this got to do with art," he demands. "The crime has to be investigated." "Not each action can be read as a crime," replies Pavlensky. Gradually, patiently and articulately, using numerous examples from the history of political art, from Andrei Rublev through Malevich and Punin to himself. Pavlensky draws Jasman around to the point that it is the context of an action that determines whether it is art or not and a crime or not. Striking a child might be a crime, argues Pavlensky, but not if you are doing it to prevent him putting his fingers into an electrical socket. We do not live our lives entirely on the plane of the criminal code. It is a symbolic field that supplies merely one part of the context our actions. Jasman at first attempts to scold Pavlensky, telling him "you must not think so globally," "you must think more narrowly," but Pavlensky insists that the meaning of art is connected to the history of art, which is always about overcoming conventional boundaries. And more generally, culture, he demonstrates, always provides the interpretive context in which all our actions are understood. But he shows that culture is not an absolute fixed context. He persuades Jasman that whereas one can easily see how the Russian interfer- 
ence in Ukraine is an act of vandalism and terrorism against which Ukrainians have the right to protect themselves, setting fire to a pile of tires on an empty bridge in St Petersburg is a purely symbolic act that harms no one. The Russian authorities are straining to have it interpreted within the cultural framework that suits them, but Pavlensky repeatedly demonstrates that the understanding supplied by the official cultural context is a dehumanizing one. So, when Jasman reveals that he is being pressured to pursue this case by his superiors, Pavlensky says: "So you agree that you are just a tool. The government simply makes tools out of people." Jasman says: "I agree” (De Winne, 2014). Just how completely Jasman had been converted became evident when the Investigative Committee attempted to carry on after his resignation and Jasman offered to appear in court as Pavlensky's lawyer (Sedacca, 2015).

In summary, then, I believe that Pavlensky has employed the process of transduction to show that if a work changes meaning according to the culture within which it is interpreted, we can invert the equation and use the work to interpret the culture. Let us represent the first culture by means of the symbolic field embodied in the Russian Criminal Code; the second culture is represented by the symbolic field embodied in the history of modern political art. By ensuring that both fields of interpretation will be brought to bear upon a single work of art, Pavlensky has juxtaposed the two cultures and shown how one of them inevitably perpetuates injustice. Does Pavlensky's method have the potential of taking all of Russia on the transductive journey through which he guided Pavel Jasman? Perhaps it would be unrealistic to expect such a result. But he seems to have at least opened a little crack in the monolithic wall that the authorities have been building to control the interpretation of truth.

\section{References}

Agence France-Presse. (2015, November 9). Russian artist arrested for setting fire to security service HQ. The Guardian. Retrieved from https://www.theguardian.com/world/2015/nov/09/russian-artist-pyotr-pavlensky-sets-fire-to-fsb-hq 
Artist Peter Pavlensky nailed to the cobblestones on Red Square [original in Russian]. (2013, November 11). Retrieved from http://graniru.org/Politics/Russia/activism/m.221013.html

De Winne, L. (2014, July 7). Interrogation of Petr Pavlensky: A play in three acts [original in Russian]. Retrieved from https://snob.ru/selected/entry/77648

Ekow, E., Omidi, M., Rann, J. \& Zinatulin, I. (2014, November 14). The naked truth: The art world reacts to Pyotr Pavlensky's Red Square protest. The Calvert Journal. Retrieved from http: // calvertjournal. com/articles/show/1768/pyotr-pavlensky-russian-artist-nailsred-square

Galperina, M. (2013, November 11). Artist who nailed his scrotum to the ground in Red Square feels 'fine'. Animal New York. Retrieved from http://animalnewyork.com/2013/artist-nailed-scrotumred-square-feels-fine/

Hlyupin, P. (2014, October 19). Artist Pavlensky cut off his earlobe. Slon. Retrieved from http://slon.ru/fast/russia/khudozhnik-pavlenskiy-otrezal-sebe-mochku-ukha-1173405.xhtml

In Vilnius, created a monument to the Russian artist Pavlensky. (2016, March 14). Newsme. Retrieved from http://newsme.com.ua/en/ world/3330421/

Lichtfilm. (2016, January 4). Trailer Pavlensky [video file]. Retrieved from https://vimeo.com/161187754

Luhn, A. (2014a, March 25). Russian protester's sentence of indefinite psychiatric treatment upheld. The Guardian. Retrieved from https:// www.theguardian.com/world/2014/mar/25/sentence-indefinite-psychiatric-treatment-protester-mikhail-kosenko 
Luhn, A. (2014b, October 20). Russian artist cuts off earlobe in protest at use of forced psychiatry on dissidents. The Guardian. Retrieved from https://www.theguardian.com/world/2014/oct/20/russian-artist-cuts-off-earlobe-protest-forced-psychiatric-treatmentdissidents

Moyer, J. (2015, November 3). Chris Burden: Why 'extreme' artist was shot, kicked and crucified. The Washington Post. Retrieved from https://www.washingtonpost.com/news/morning-mix/ $\mathrm{wp} / 2015 / 05 / 11 /$ why-extreme-chris-burden-was-kicked-shotand-crucified-for-art/

Nechepurenko, I. (2015, July 28). How Russia's 'most controversial artist' persuaded his interrogator to change sides. The Guardian. Retrieved from https://www.theguardian.com/world/2015/jul/28/petr-pavlensky-artist-scrotum-red-square-interrogator

Pavlensky refused the termination of criminal case for action "Freedom." (2016, April 26). [Original in Russian]. Retrieved from http:// www.svoboda.org/a/27699017.html

Remax 1162. (2012, July 7). Young artist Peter Pavlensky sewed his mouth [Original in Russian] [Video file]. Retrieved from https://www. youtube.com/watch?v=g5SvDhorfz8

Russian artist arrested for setting fire to security service HQ. (2015, November 09). The Guardian. Retrieved from https://www.theguardian. com/world/2015/nov/09/russian-artist-pyotr-pavlensky-sets-fire-to-fsb-hq

Russia Update: FSB seals entrance of Lubyanka as artist Pavlensky awaits determination of his case. (2015, November 10). The Interpreter. Retrieved from http://www.interpretermag.com/russia-updatenovember-10-2015/ 
Sedacca, M. (2015, September 18). Russian actionist Petr Pavlensky talks censorship in the motherland. The Creator's Project. Retrieved from http://thecreatorsproject.vice.com/blog/a-russian-artist-pokedthe-bear-and-almost-got-away-with-it

Serebrennikov, K. (2013, November 11). Message posted to: https://www. facebook.com/kirill.serebrennikov

Skameikin, G. [Gleb Skameikin]. (2013, May 4). Nude artist Peter Pavlensky in barbed wire - in front of the Legislative Assembly in St. Petersburg [Video file]. Retrieved from https://www.youtube.com/ watch?v=d8r3e1HhIpQ

Stanglin, D. (2014, April 16). Hooliganism case against Red Square scrotum artist dropped. The Moscow Times. Retrieved from https:// themoscowtimes.com/news/hooliganism-case-against-red-square-scrotum-artist-dropped-34055

Universidad del Norte. (2016). Cultural Transduction Conference. Retrieved from http://www.uninorte.edu.co/web/eventos/culturaltransduction

Walker, S. (2013, November 11). Artist nails his scrotum to the ground in Red Square. The Guardian. Retrieved from https://www.theguardian.com/world/2013/nov/11/artist-nails-testicles-red-squarepyotr-pavlensky

Walker, S. (2014, February 2). Petr Pavlensky: Why I nailed my scrotum to Red Square. The Guardian. Retrieved from https://www.theguardian.com/artanddesign/2014/feb/05/petr-pavlensky-nailed-scrotum-red-square

Walker, S. (2015, August 25). Russian court jails Ukrainian filmmaker for 20 years over terror offences. The Guardian. Retrieved from 
https://www.theguardian.com/world/2015/aug/25/russiancourt-jails-ukrainian-filmmaker-oleg-sentsov-for-20-years-overterror-offences

Whitmore, B. (2007, September 10). Russia: Powerful new investigative body begins work. RadioFreeEurope/RadioLiberty. Retrieved from http://www.rferl.org/a/1078611.html 